\title{
Erysiphe cichoracearum em Acalypha wilkesiana no Brasil
}

\author{
Reginaldo G. Mafia, Acelino C. Alfenas, Eraclides M. Ferreira \& Gabriela C. G. Andrade \\ Departamento de Fitopatologia, Universidade Federal de Viçosa, UFV, CEP 36570-000, Viçosa, MG, e-mail: \\ aalfenas@ufv.br
}

(Aceito para publicação em 09/08/2004)

Autor para correspondência: Acelino Couto Alfenas

\begin{abstract}
Erysiphe cichoracearum on Acalypha wilkesiana in Brazil

The incidence of powdery mildew, caused by Erysiphe cichoracearum is reported for the first time on Acalypha wilkesiana in Brazil. The fungus was identified based on its morphological characteristics on the light microscope.
\end{abstract}

Acalypha wilkesiana Mull. Arg., pertencente à família Euphorbiaceae, é popularmente conhecida como acalifa, crista-de-peru ou rabo de macaco. São plantas arbustivas, semi-lenhosas e perenes utilizadas amplamente para fins de ornamentação, uma vez que, apresentam folhas de formato e coloração variada (Figura 1A e B) (Lorenzi, H. \& Souza, H.M. Plantas Ornamentais no Brasil. 1088p. 2001). Em uma inspeção de rotina no campus da Universidade Federal de Viçosa (UFV), contatou-se a incidência de míldio pulverulento sobre folhas (Figura 1C) de duas variedades de A. wilkesiana. Exames microscópicos evidenciaram a presença de um fungo semelhante a espécies do gênero Oidium. Para realizar a caracterização morfológica, avaliaram-se 50 estruturas anamórficas obtidas de plantas com infecção natural, além do padrão de germinação típico. Para avaliar quanto à presença de corpos de fibrosina, conidióforos e conídios foram montados em solução aquosa de KOH 3\% [Braun, U. A monograph of the Erysiphales (Powdery Mildews) 1987]. Os exames microscópicos evidenciaram comprimento da célula do micélio $(50,0-90,0 \mu \mathrm{m})$, altura e posição do septo basal do conidióforo $(0,5-1,0 \mu \mathrm{m})$ e dimensões $(50-80 \times 9-15 \mu \mathrm{m})$ do conidióforo, bem como dimensões (25-42 x 14-22 $\mu \mathrm{m}) \mathrm{e}$ formato (ovóide a cilíndrico) dos conídios típicos de Erysiphe cichoracearum DC. (Figura 1D). Além destas características, observou-se ausência de corpos de fibrosina e ocorrência de germinação dos conídios do tipo "cichoracearum" [Boesewinkel, H.J. The morfology of the imperfect states of powdery mildews (Erysiphaceae). The Botanical Review 46:167-224. 1980]. Para comprovação da patogenicidade, folhas sadias de $A$. wilkesiana foram inoculadas mediante pincelamento de esporos e em seguida mantidas em câmara úmida. Plantas pinceladas com água estéril serviram como testemunha. Após dez dias de inoculação, as folhas inoculadas apresentavam os mesmos sintomas e sinais observados em condições de infecção natural, comprovando a etiologia da doença. Este mesmo patógeno é relatado como agente etiológico de oídio em acalifa na Flórida (EUA) (Jr. Alfieri, S.A., Langdon, K.R., Wehlburg, C. \& Kimbrough, J.W. Index of plant disease in Florida. 389p. 1984), sendo este seu primeiro relato no Brasil.

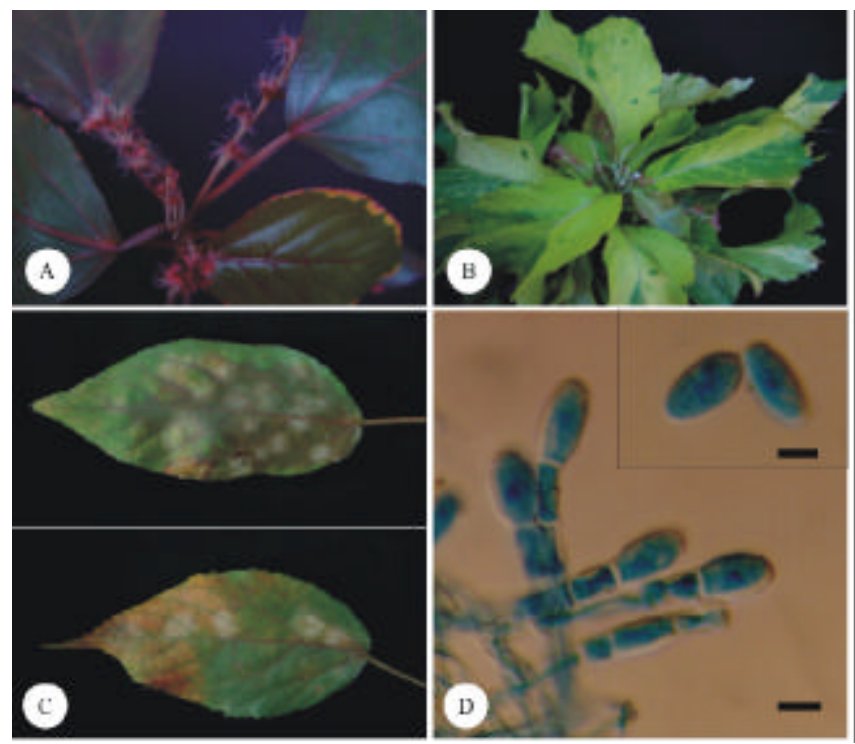

FIG. 1 - Sintomas e sinais do míldio pulverulento em Acalypha wilkesiana: A e B- Variedades distintas de acalifa evidenciando folhas de formato e coloração variada; C- Sintomas do míldio pulverulento em folhas; e D- Conidióforos e conídios típicos do Erysiphe cichoracearum. Barras $=15 \mu \mathrm{m}$. 